\title{
Exchange Rate Pass-Through: To What Extent do Prices Change in Sri Lanka?
}

\author{
S. M. Wimalasuriya ${ }^{1}$
}

\begin{abstract}
This paper examines exchange rate pass-through into prices in Sri Lanka. The relevance of the study lies in the fact that domestic price changes due to changes in the exchange rate could be significant in monetary policy decision making. Pass-through is estimated taking two approaches. First, pass-through into import prices is estimated with the use of a log-linear regression model. The results obtained suggest that exchange rate pass-through into import prices is around fifty per cent, that is, import prices increase by about 0.5 per cent as a result of a 1 per cent depreciation of the nominal effective exchange rate. Second, taking a vector autoregressive approach, exchange rate pass-through into a set of prices in the "pricing chain" is estimated. Namely, exchange rate pass-through to factor input prices, trade prices, wholesale producer prices and retail consumer prices, is examined, with the presumption that changes in the exchange rate are due to shocks exogenous to the model. The results obtained for this model suggest that exchange rate pass-through into consumer prices is about thirty per cent, although pass-through into wholesale producer prices was found to be complete. The findings from the second model further suggest that changes in the exchange rate could have significant implications for the trade balance. (JEL E31 E52)
\end{abstract}

\section{Overview}

\section{A. Introduction}

Price stability being a core objective of the central bank, and given that monetary policy is the tool with which the central bank has to achieve price stability, it is important to understand those factors which govern or impact upon the effectiveness of monetary policy. It is in this context that a clear understanding of exchange rate pass-through, that is, how changes in the external value of the domestic currency affect domestic prices, is important, the exchange rate being a channel of monetary policy transmission.

The significance of exchange rate pass-through in understanding how prices behave in the domestic economy is further heightened by the fact that domestic markets are becoming increasingly integrated with global markets, with the liberalisation of the domestic economy

1/ The author wishes to thank Dr. P N Weerasinghe, in particular, and Mr. B D W A Silva, for their valuable comments. 
beginning in the late 1970s. Accordingly, exchange rate-pass-through is likely to become increasingly more important in the external adjustment of the country, which in turn has significant implications for the monetary conditions within the country including the behaviour of prices. Hence, an analysis of domestic prices in relation to changes in the exchange rate is important, especially in the context of the floating exchange rate regime that has been in operation since 2001 .

\section{B. Significance of the Study}

As stated above, exchange rate pass-through could be broadly defined as the relationship between the changes in the nominal exchange rate and the domestic price level. At a disaggregate level, exchange rate pass-through could be assessed in respect of different industries or with respect to various categories of goods such as consumer goods, intermediate goods and investment goods.

Particularly in the case of small, open, developing countries such as Sri Lanka, an external shock could exert pressure on the exchange rate, resulting in the depreciation of the domestic currency. While such a change in the external price of the currency affects domestic prices of consumer goods, intermediate goods as well as investment goods, some of these price changes could result in further increases in prices. For instance, prices of intermediate goods could indirectly impact on consumer goods as well as investment goods. One example would be oil prices, which tend to have a significant impact on consumer prices, when both direct and indirect effects of changes in oil prices are taken together. Meanwhile, wages, particularly if they are indexed to consumer price indices, tend to increase in turn, if consumer price increases persist. Hence, primary and secondary effects of an exchange rate depreciation following an external shock could have a spiralling effect on inflation, particularly if the central bank is slow in responding to such a price shock.

Comparison of exchange rate pass-through in Sri Lanka with that of countries of interest could also offer useful information. Across countries, exchange rate-pass through differs depending on a number of factors. At a micro level, these factors include firms' expectations about the persistence of the change and the prevailing market structure in different industries. The output gap and inflation expectations are two macroeconomic factors that impact on the exchange rate-pass through.

The degree of exchange rate pass-through affects the effectiveness of monetary policy mainly through expenditure switching effects, with low exchange rate pass-through generally being more supportive of monetary policy effectiveness. This is because if exchange rate pass through is high, then people are more likely to switch to imported products that are relatively cheaper compared to domestically produced goods in times of monetary tightening in the face of an external shock for instance, thus reducing the effect of the policy action. In any case, given that the degree of exchange rate pass through, that is, both the extent and speed of change in domestic prices in response to a change in the external value of the domestic currency, has implications for the timing of monetary policy, a thorough understanding of the exchange rate pass-through in Sri Lanka is warranted.

\section{Objectives of the Study}

- To establish how much and how fast domestic prices change in response to a change in the exchange rate, in Sri Lanka.

- To examine the impact of a change in the exchange rate on factor input prices, trade prices, wholesale producer prices and consumer prices, i.e., prices along the 'pricing chain'.

- To ascertain changes, if any, in exchange rate pass-through in Sri Lanka.

\section{Scope and Method of Study}

In this paper, pass-through would be studied in terms of two models. The first model is a log-linear regression model that has been tested in the exchange rate pass through literature, aimed at assessing the response of import prices to changes in the exchange rate, taking into consideration important control variables.

The second is a vector autoregression (VAR) model, aimed at estimating exchange rate pass-through into a set of prices along the pricing chain, i.e., factors input prices, trade prices, wholesale producer prices and consumer prices. The impact of a structural shock such as an asset market disturbance giving rise to a change in the exchange rate, would be studied by way of this VAR model.

On the basis of data availability, the models would be estimated with data of a monthly frequency, for the period 2000 to 2005. Given that some of the variables used in the above models are not directly available, proxy variables would be used, which will be chosen on the basis of their economic and econometric properties.

\section{E. Chapter Outline}

This paper is organised as follows. In Chapter I, the background information pertaining to the issues being studied was presented. The specific objectives of the study, the significance of the study as well as how the researcher intends to go about studying the issues being raised were also presented in Chapter I. In Chapter II, the literature on exchange rate pass-through will be discussed in detail. Chapter III will deal with the analytical framework, namely, the econometric models used for assessing the degree of exchange rate pass-through in Sri 
Lanka. The data employed to estimate these models will also be discussed in this chapter Chapter IV will present the findings as per the models estimated. These findings will be compared with the findings of other researchers, who have studied exchange rate pass-through in other parts of the world. The final chapter, Chapter V, will present the conclusions of the study as well as recommendations for further study.

\section{Review of Literature}

\section{A. Introduction}

The focus of literature on exchange rate pass-through has shifted over time. From the earlier focus on purchasing power parity, that is, the law of one price and convergence across countries, the focus of studies in the 1980s shifted to industrial organisation and the role of segmentation and price discrimination across geographically distinct product markets. More recently, studies on exchange rate pass-through have been in relation to monetary policy and exchange rate optimality. Meanwhile, some writers uncover evidence of structural changes in relation to trade as an important factor underlying the recent changes in exchange rate pass-through with respect to some countries.

Given that this paper analyses exchange rate pass-through in Sri Lanka in the context of its implications for monetary policy, the literature reviewed hereunder largely focus on exchange rate pass-through in relation to changes in domestic prices and monetary policy.

\section{B. Degree of Exchange Rate Pass-Through: Reasons and Implications} for Monetary Policy

Mishkin (1996) points out that with the growing internationalisation of economies throughout the world and the advent of flexible exchange rates, increasingly more attention is paid to monetary policy transmission operating through exchange rate effects on net exports.

As Fiore (1998) explains, the transmission of monetary policy through the exchange rate channel takes place as follows: when the monetary base is reduced by a rise in domestic real interest rates, the supply of the national currency falls and its price relative to the price of foreign currencies rises. This amounts to an appreciation of the exchange rate, which in turn would affect output in tradable sectors by increasing imports and decreasing exports. However, the net impact of a tightening (or a loosening) of monetary policy on tradable sectors would depend on the degree of exchange rate pass-through into these sectors.

Fiore, discussing the transmission of monetary policy in Israel, points out that in Israel, "At a sectoral level, industrial sectors open to trade appear to suffer from monetary policy shocks to a larger extent than sectors closed to trade, because of their exposure to the exchange rate channel." She goes on to point out that "Open sectors with a high value added and a low wage share, however, may be able to partially insulate themselves from the exchange rate channel."

Kiptui et al. (2005) highlight that the level of exchange rate pass-through has implications for the timing of monetary policy intervention. In particular, in forecasting inflation and formulating monetary policy in response to an external shock to inflation, knowledge of the speed and the extent of exchange rate pass-through is required, as they point out. This is particularly true if the share of imports is significant in aggregate consumption. Further, as the potential for second-round pass-through of price increases rises, implications of exchange rate pass-through for monetary policy become more significant in the event of an actual or potential significant change in the nominal exchange rate.

Discussing partial pass-through, the costs to firms in adjusting prices, i.e., menu costs, uncertainty as to whether the import price movements are permanent or cyclical and the desire to maintain market share by "pricing-to-market", are cited by Kiptui et al. as some of the reasons for firms opting to vary their margins in response to changes in the exchange rate and the consequent changes in their costs. At a macroeconomic level, exchange rate volatility and volatility in aggregate demand (proxied by the output gap) are cited by them as factors leading to lower pass-through. While they also discuss some possible reasons for varying levels of pass-through in different countries, they draw attention to the finding by various economists, of partial pass-through of exchange rate changes into prices in most countries.

Devereux and Yetman (2003) also point to the substantial literature covering many countries, which document low exchange rate pass-through both at a disaggregated level and at the level of aggregate prices. They contrast these findings with the expectation of many economists in the early years of floating exchange rates to find a close association between movements in exchange rates and national price levels.

Referring to the debate on the causes of low exchange rate pass-through, Devereux and Yetman summarise the explanations put forth by various economists, both microeconomic and macroeconomic. Amongst the microeconomic explanations of low exchange rate pass-through cited by them are structural features of international trade such as pricing to market by imperfectly competitive firms, domestic content in the distribution of traded goods, the role of substitution between goods in response to changes in exchange rates, and the changing composition of imported goods. On a macroeconomic level, the slow adjustment of goods prices at the consumer level, i.e., sticky prices, is according to them a key reason cited by economists for the low exchange rate pass-through. Devereux and Yetman conclude that their findings also confirm that sticky prices play an important role in cross-country variations in exchange rate pass-through. Accordingly, they argue that exchange rate pass-through is endogenous to the monetary policy regime. Specifically, they conclude that 
when firms can adjust their frequency of price changes, "looser" monetary policy leads to more frequent price changes and therefore higher depreciation and higher pass-through. Hence, they agree with Taylor (2000), who posits that pass-through is systematically related to monetary policy.

Accroding to Devereux and Yetman, in general, the optimal frequency of price changes would vary with the monetary policy regime. They point out that, firms will choose a higher frequency of price adjustment, the higher the average rate of inflation, which tends to result in higher variability in the exchange rate. The higher frequency of price changes, they point out, would result in greater exchange rate pass-through. They also cite the findings in a paper by Choudri and Hakura (2001), namely, that exchange rate pass-through tends to vary systematically with the mean inflation rate, as being similar to their own findings about the relationship between exchange rate pass-through and inflation, and therefore monetary policy. While they conclude that pass-through increases (in a non-linear fashion) with increases in both mean inflation and mean exchange rate depreciation, they suggest that this endogenous nature of exchange rate pass-through be taken into account in designing monetary policy for a small open economy.

Gagnon and Ihrig (2004) who study the decline in pass-through of exchange rate changes into domestic inflation in twenty industrial countries since the 1980s, conclude that it can be attributed to the increased emphasis on inflation stabilisation by many central banks. They show that, countries with low and stable inflation, which they attribute to central bank policies, have low estimated pass-through. While their empirical results indicate a statistically significant link between the decline in the level and the variability of inflation, and the decline in exchange rate pass-through, they explain that, when a central bank's commitment to keeping inflation low is credible, firms are less inclined to quickly pass higher costs on to consumers in the form of higher prices.

While there is now a large body of literature, which support the view that there is a significant link between inflation and therefore monetary policy and the degree of exchange rate pass-through, the change in the focus of discussions on exchange rate pass-through, from the pricing power of firms to inflation and monetary policy, is largely attributed to John B. Taylor. In the paper titled "Low Inflation, Pass-Through, and the Pricing Power of Firms", 2000 , he put forth the view that the reduction in the degree to which firms pass-through cost increases due to exchange rate movements or other factors is due to lower and more stable inflation, that is, the low inflation environment that has been achieved by many countries by the early 1990s. Although economists had at that time attributed this lower inflation to such factors as the absence of "shocks", favourable structural changes, a decline in pricing power of firms, a decrease in the natural rate of unemployment due to demographic factors and/or an increase in potential GDP due to higher productivity growth, Taylor was of the opinion that the primary cause was a change in monetary policy. In his paper, while he concludes that lower pass-through is caused by lower inflation, he is of the view that a change of monetary policy and a return to higher inflation expectations would result in a higher level of pass-through. The main point of his paper, as he stresses, is that, lower pass-through should not be taken as exogenous to the inflationary environment. This is because, as he explains, the general inflationary environment affects the pricing behaviour of firms. In this context, he highlights the importance of assessing the degree of pass-through for forecasting inflation and for deciding how much to tighten monetary policy in response to an increase in inflation that can be identified with a change in the exchange rate.

Adolfson (2001) highlights the significance of the exchange rate for small open economies, given that it impacts inflation directly through import prices as well as indirectly, through aggregate demand. However, he stresses that empirical evidence for both large and small open economies seem to suggest that there are systematic deviations from the law of one price, and that exchange rate pass-through is incomplete both for export and import prices. He goes on to suggest that these nominal rigidities imply that it is expectations about future exchange rate movements and future inflation that play an important role in the inflation-output relation.

Adolfson obtains three main results in his paper. First, he concludes that the monetary policy response to both foreign and domestic shocks depends on the degree of exchange rate pass-through. In this regard, he notes that as the exchange rate channel has less impact when pass-through is low, this in turn implies that foreign shocks require smaller interest rate adjustments. Second, he notes that incomplete pass-through implies less conflict between inflation and output variability because of the lower exposure to exogenous as well as policy induced exchange rate fluctuations. Third, he notes that volatility of the nominal exchange rate increases as pass-through decreases. With respect to this last observation, he explains that, given import price stickiness (due to 'menu' costs, producers' concern for reputation due to imperfectly informed consumers and brand-switching costs in the domestic market), the required relative price adjustment is generated through larger movements in the exchange rate.

Empirical results obtained by Campa and Goldberg (2002) point to partial pass-through across the $\mathrm{OECD}^{2}$ countries in the short-run ${ }^{3}$. Hence they reject the prevalence of both producer-currency-pricing and local currency pricing of imports in OECD countries, in the short-run. However, they find evidence of producer-currency-pricing for many types of imported goods in the long-run.

As they point out, low exchange rate pass-through into import prices means that nominal exchange rate fluctuations may lead to lower expenditure switching effects of domestic

2/ Organisation for Economic Cooperation and Development

3/ They find that the unweighted average of pass-through elasticities for OECD countries is about 60 per cent over one quarter (i.e., in the short-run), and nearly 80 per cent over the longer term (i.e., one year). They also find that the USA has the lowest exchange rate pass-through, at around 25 per cent in the short-run and around 40 per cent over the longer term. 
monetary policy, thereby leaving monetary policy more effective for dealing with real shocks. In this regard, they note that if pass-through rates are endogenous to a country's relative monetary stability, as was hypothesised by Taylor (2000), the extent of this monetary policy effectiveness would be fragile and regime specific. But, on the basis of the empirical results obtained by them, Campa and Goldberg claim that 'the Taylor argument' is not of first order importance for the low and medium inflation OECD countries. They emphasise that, despite lower inflation in many OECD countries in recent years, declining exchange rate pass-through into import prices is not a general feature of OECD countries, with levels of pass-through being significantly higher in countries with higher nominal exchange rate variability and higher average inflation. According to Campa and Goldberg, with respect to pass-through rates in the OECD countries, most important are the changes in the composition of industries in a country's import basket. In particular, they cite the move away from energy and raw materials as a high proportion of the import bundles, to a much higher share of manufactured products (from around 50 per cent in 1980 to around 70 per cent by 1992), as the primary driver behind the recent pass-through declines into import prices in many OECD countries. They further explain that given that this change in the industry composition of trade is more structural than inflation performance, it is more robust and durable. Their findings imply that monetary policy transmission could be expected to be more robust in these countries, to the extent that industry pass-through rates remain stable.

Faruqee (2004), who examines exchange rate pass-through in a set of euro area prices along the pricing chain, concludes that exchange rate pass-through is incomplete in the euro area, which he attributes to euro-currency pricing and pricing-to-market behaviour. Accordingly, he suggests that, as in the United States of America, expenditure switching effects of the exchange rate on the current account are generally small in the euro area. This is due to the fact that incomplete pass -through could delay or diminish the response in external variables and produce a certain degree of "exchange rate disconnect", as he explains.

\section{Conclusions from the Review of Literature}

The inflation environment in the country, the composition of the import basket, and at a microeconomic level, competitiveness of domestic firms or the market structure at the industry level, have been highlighted as being important determinants of the degree of exchange rate pass-through into import prices in a country, in the literature on exchange rate pass-through. Exchange rate pass-through has been found to be incomplete in many countries. However, depending on the relative importance of the specific factors that determine the degree of exchange rate pass-through in a country, these factors must be given due consideration in forecasting inflation and formulating monetary policy, especially as there could be secondround pass-through of price changes.

\section{The Analytical Framework}

In this paper, exchange rate pass-through in Sri Lanka is examined taking two approaches. First, on the basis of a log-linear regression model, exchange rate pass-through into prices of imported goods is examined. Second, exchange rate pass-through along the pricing chain, that is, from the exchange rate to factor input prices to trade prices, i.e., import prices and export prices; to wholesale producer prices and retail consumer prices.

\section{The Models}

(i) Model 1: Log-Linear Regression Model.

$$
P_{t}=\alpha+\delta x_{t}+\gamma e_{t}+\varphi Z_{t}+\varepsilon_{t}
$$

where $P_{t}$ are local currency import prices, et is the exchange rate, $x_{t}$ is a primary 'control' variable representing foreign prices, and $Z$, which is another control variable, is the real gross domestic product (GDP) of the destination market. It is a log-linear regression specification.

As a proxy for local currency import prices, an index computed for the monthly expenditure (amounts) on imported items included in the CCPI was used (where the base year is 1999). The exchange rate series used is the nominal effective exchange rate (NEER) with 1999 as the base year, for the 5-currency basket (which reflects the movements of the Sri Lanka rupee vis-à-vis its most important trading partners). A proxy variable was used for the data series on foreign prices (x), which was constructed using the real effective exchange rate (REER) based on the Sri Lanka Consumers' Price Index (SLCPI), with 1999 as the base year, and the NEER, both for the 5-currency basket ${ }^{4}$. As data on the GDP are not available on a monthly basis, the industrial production index, which was found to be cointegrated with the GDP series (see Appendix I), was used as the proxy variable. All data series are expressed in logarithms. In estimating the model, first differences of the series were used given the presence of a unit root in all the variables included (see Appendix II). An error correction term was not included as none of the variables are cointegrated.

'The textbook definition of exchange rate pass-through is the per cent change in local currency import prices resulting from a one per cent change in the exchange rate between the exporting and importing country' (Campa and Goldberg, 2002).

However, as Campa and Goldberg point out, the microeconomic foundations of pricing behaviour are a better starting point for generating the more economically meaningful specifications for hypotheses testing. They examine exchange rate pass-through in $25 \mathrm{OECD}$ countries, using the log-linear regression model given above (model 1).

4/ $x=N E E R \cdot P^{d} / R E E R$, where $P^{d}$ is the domestic price index, which is the SLCPI. 
(ii) Model 2: Structural VAR Model.

$$
\begin{aligned}
Y_{t} & =c+A(L) Y_{t-1}+\mu ; \\
\mathrm{E}\left[\mu_{t} \mu_{t}^{1}\right] & =\Omega
\end{aligned}
$$

where $Y=[\Delta e \Delta w \Delta m \Delta x \Delta p \Delta c]^{1}, c$ is a vector of deterministic terms (i.e., monthly dummies), $A$ is a matrix polynomial of degree $p$ in the lag operator $\mathrm{L}$, and $\mu$ is the $(6 \times 1)$ vector of reduced form residuals with variance-covariance matrix $\Omega$.

The exchange rate $(e)$ is placed first, reflecting the presumption that exchange rate innovations at monthly frequency are primarily driven by factors exogenous to the model. The ordering after the exchange rate follows the pricing chain, from factor input prices $(w)$ to trade prices, i.e., import prices $(m)$ and export prices $(x)$; to wholesale producer prices $(p)$ and retail consumer prices $(c)$. All series are expressed in logarithms. In estimating the model, first differences were used, considering the presence of a unit root in most variables (see Appendix III), and with the aim of estimating the accumulated response to an exchange rate shock, on the basis of impulse response functions, over a period of one and a half to two years.

The exchange rate series used is the nominal effective exchange rate with 1999 as the base year, for the 5-currency basket, as it reflects the movements of the Sri Lanka rupee vis-à-vis its most important trading partners, as mentioned before. As a proxy for factor input prices, the real wage rate index for workers in the Wages Boards Trades, that is, the Combined Index for workers in Agriculture, Industry and Commerce, and Services, with 1978 as the base year, was used. Import and export price indices, which are unit value indices with 1997 as the base year, are the indices computed for trade prices in US dollar terms. As a proxy for the series on wholesale producer prices, the wholesale price index for intermediate goods, with the base year of 1974, was used. (Amongst the items covered by the wholesale price index for intermediate goods are fertiliser including urea, phosphate, sulphate ammonia and rock phosphate; wheat grain; citronella oil; cocoa; tobacco; cardamom; rubber (RSS2); fuel including kerosene, petrol and diesel; electricity; cotton yarn; bulbs; switches; fans; insulated wires; dry battery cells; chrome leather; zinc oxide; zinc chloride; wood pulp; mammoties; and tyres for bicycles, tractors, lorries and cars). The series on consumer prices is the Colombo Consumers' Price Index, with the base year of 1952, which is the official price index. An error correction term was not included in the model as there was no cointegration among these variables.

The empirical approach associated with model 2 closely follows Faruquee (2004). While he estimates exchange rate pass-through into domestic prices in the Euro area using a vecto autoregression (VAR) model, he cites several advantages of the use of a VAR approach to examine exchange rate pass-through. First, the types of underlying exchange rate shocks (for example, whether permanent or transitory), may be distinguished. Second, the relative degree of pass-through into different prices along the pricing chain may be determined.

Sims' (1980) vector autoregressive (VAR) approach has the property of treating all variables included in the model symmetrically. A structural VAR differs from a VAR in this aspect, because it involves imposing restrictions on selected variables, given that the aim of using a structural VAR is to use economic theory.

The researcher intends to examine the impact of a unit change in the (nominal, trade weighted effective) exchange rate on the set of prices along the 'pricing chain', that is, factors input prices, trade prices, wholesale producer prices and consumer prices, in Sri Lanka. Accordingly, following the methodology used by Faruqee (2004), a structural VAR was estimated, from which the relevant impulse response functions were obtained, which trace out the time path of the shock, i.e., the effect of a change in the nominal effective exchange rate, on the other prices in the structural VAR system; namely, factors input prices, trade prices, wholesale producer prices and consumer prices.

The structural VAR model was estimated imposing restrictions so that only those variables placed upstream in the pricing chain affect the changes in any given variable in response to an exchange rate shock. In other words, the contemporaneous values of downstream prices do not have a contemporaneous effect on any of the prices in the system The imposition of this identification restriction by using Choleski decomposition implies an ordering of the prices within the system. Impulse responses to an exchange rate shock were thereafter obtained.

\section{Analysis and Findings}

\section{A. Model I - Finding}

The exchange rate was found to have a significant impact on import prices, with a lag. The Durbin-Watson Statistic was found to be very close to 2, suggesting that the model specification was appropriate, that is, all relevant variables have been included. However the R-squared value was found to be only 0.38 .

The response of import prices to a change in the exchange rate was found to be prolonged, with the most significant adjustment in import prices taking place after eight months. The empirical estimates from the model suggest that import prices increase by a total of about 0.5 per cent during a period of around eight months, following a depreciation of the exchange rate by 1 per cent, or vice versa (see Table 1). 


\section{Table 1 - Exchange Rate Pass-Through into Import Prices in Sri Lanka}

(Results for the Log-Linear Regression)

Dependent Variable: Import Prices

Method: Least Squares

Date: 07/22/06 Time: 10:53

Sample(adjusted): 2000:10 2005:12

Included observations: 63 after adjusting endpoints

\begin{tabular}{|c|c|c|c|c|}
\hline Variable & Coefficient & Std. Error & t-Statistic & Prob. \\
\hline C & 0.004167 & 0.007406 & 0.562624 & 0.5769 \\
\hline Foreign Prices & -0.127875 & 1.131654 & -0.112998 & 0.9106 \\
\hline Foreign Prices (-1) & -2.313532 & 1.105623 & -2.092515 & 0.0429 \\
\hline Foreign Prices (-2) & -0.432264 & 1.006209 & -0.429596 & 0.6699 \\
\hline Foreign Prices (-3) & 0.981248 & 1.027704 & 0.954796 & 0.3456 \\
\hline Foreign Prices (-4) & -0.931754 & 1.073981 & -0.867570 & 0.3909 \\
\hline Foreign Prices (-5) & 0.958187 & 1.052721 & 0.910200 & 0.3683 \\
\hline Foreign Prices (-6) & 1.922476 & 1.111375 & 1.729818 & 0.0916 \\
\hline Foreign Prices (-7) & 0.833222 & 0.966999 & 0.861657 & 0.3941 \\
\hline NEER & -0.192017 & 0.170694 & -1.124921 & 0.2675 \\
\hline $\operatorname{NEER}(-1)$ & -0.238960 & 0.169285 & -1.411583 & 0.1660 \\
\hline NEER (-2) & 0.280861 & 0.171746 & 1.635331 & 0.1100 \\
\hline NEER $(-3)$ & 0.029933 & 0.175369 & 0.170686 & 0.8654 \\
\hline NEER (-4) & 0.194425 & 0.170740 & 1.138722 & 0.2618 \\
\hline NEER $(-5)$ & -0.118934 & 0.164839 & -0.721516 & 0.4749 \\
\hline NEER (-6) & -0.103671 & 0.171705 & -0.603773 & 0.5495 \\
\hline NEER (-7) & 0.134120 & 0.170299 & 0.787557 & 0.4357 \\
\hline NEER (-8) & -0.483661 & 0.172211 & -2.808530 & 0.0077 \\
\hline GDP & 0.048127 & 0.033090 & 1.454435 & 0.1538 \\
\hline $\operatorname{GDP}(-1)$ & 0.042788 & 0.039663 & 1.078801 & 0.2873 \\
\hline GDP $(-2)$ & -0.022202 & 0.039296 & -0.564977 & 0.5753 \\
\hline GDP $(-3)$ & 0.045952 & 0.047862 & 0.960101 & 0.3429 \\
\hline GDP $(-4)$ & 0.096801 & 0.056177 & 1.723119 & 0.0928 \\
\hline GDP (-5) & 0.080870 & 0.046112 & 1.753758 & 0.0873 \\
\hline R-squared & 0.383985 & Mean dependent var & & 0.008756 \\
\hline Adjusted R-squared & 0.020694 & S.D. dependent var & & 0.015307 \\
\hline S.E. of regression & 0.015148 & Akaike info criterion & & -5.259628 \\
\hline Sum squared resid & 0.008948 & Schwarz criterion & & -4.443195 \\
\hline Log likelihood & 189.6783 & F-statistic & & 1.056962 \\
\hline Durbin-Watson stat & 1.983086 & Prob(F-statistic) & & 0.428480 \\
\hline
\end{tabular}

The control variables, that is, both foreign prices and GDP, were also found to have a significant impact on import prices, with a lag. It was found that import prices increase by a total of around 0.05 per cent during a period of six months, in response to an increase in foreign prices by 1 per cent. With respect to the impact of economic activity on import prices, it was found that import prices increase by about 0.3 per cent within a period of around 5 months, in response to an increase in the GDP by 1 per cent.

While these findings suggest that exchange rate pass-through is incomplete in Sri Lanka, at about 50 per cent, this phenomenon has been found to be common to many countries, with some of the effect of a change in the exchange rate being absorbed in the mark-ups of the exporters or the profit margins of importers. Amongst the OECD countries, the USA has been found to be a country with very low exchange rate pass-through into import prices, at about 25 per cent. In contrast, exchange rate pass-through has been found to be complete within a year or so in several OECD countries including Portugal, the Netherlands, Ireland, Italy and Japan. However, in many countries, it has been found that exchange rate pass-through is incomplete, as stated before. For example, after one year, total pass-through into import prices is estimated at around 27 per cent for Greece, around 34 per cent for Norway, around 56 per cent for the UK, around 73 per cent for Germany and around 80 per for the Czech Republic. (The import pass-through elasticities for other countries are estimates by Campa and Goldberg, 2002).

Graph 1 - Effect of an Exchange Rate Shock on Prices (Effect of a unit structural shock)

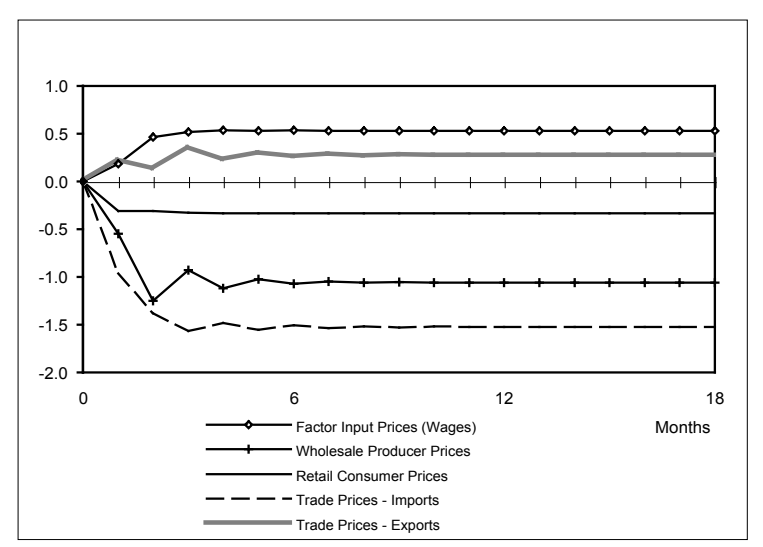




\section{Table 2 - Pass-Through Elasticities*}

(Per cent change in prices divided by per cent change in exchange rate)

\begin{tabular}{lrrrrr}
\hline & $\mathrm{T}=1$ & $\mathrm{~T}=3$ & $\mathrm{~T}=6$ & $\mathrm{~T}=12$ & $\mathrm{~T}=18$ \\
\hline Factor Input Prices (Wages) & 0.19 & 0.52 & 0.53 & 0.53 & 0.53 \\
Trade Prices - Imports & -0.96 & -1.57 & -1.50 & -1.52 & -1.52 \\
Trade Prices - Exports & 0.22 & 0.34 & 0.25 & 0.27 & 0.27 \\
Wholesale Producer Prices & -0.55 & -0.93 & -1.07 & -1.06 & -1.06 \\
Retail Consumer Prices & -0.31 & -0.33 & -0.33 & -0.33 & -0.33 \\
\hline
\end{tabular}

* Pass-through elasticities are accumulated elasticities, up to the selected time period, where $T$ refers to the number of months. Based on impulse response functions from the structural VAR model.

\section{B. Model II - Findings}

The VAR approach to the analysis of the impact of a change in the exchange rate reveals that retail consumer prices in Sri Lanka increase by about 0.3 per cent in the long run in response to a depreciation of the nominal effective exchange rate by 1 per cent ${ }^{5}$. The pass-through to wholesale producer prices, in contrast, becomes complete within about 6 months. The pass-through to worker compensation (factor input prices), which is positively related to the nominal effective exchange rate, is about 50 per cent in the long run, suggesting that the purchasing power of workers increases by about 0.5 per cent with an appreciation of the nominal effective exchange rate by 1 per cent. With respect to trade prices, given the relatively much larger response of import prices to a change in the exchange rate, compared to the response of export prices, movements in the exchange rate appear to have significant implications for the trade balance.

\section{Summary and Conclusions}

The exchange rate is one of the factors, which determine the behaviour of domestic prices With the liberalisation of the domestic economy, domestic markets are becoming increasingly integrated with global markets, which is likely to further heighten the importance of the exchange rate for the movements of domestic prices. Another important factor in this regard is the fact that there would be some degree of second-round pass through of price increases, if domestic prices increase as a result of a depreciation of the rupee. Hence, exchange rate pass-through should necessarily be given due consideration in the formulation of monetary policy for Sri Lanka.

5/ Wijesinghe (1990) found that, during the period 1982-1987, a 1 per cent depreciation of the exchange rate induced a 0.59 per cent increase in consumer prices, of which 80 per cent takes place within a year.
In this paper, exchange rate pass-through in Sri Lanka was examined taking two approaches. First, a log-linear regression model was estimated to determine the degree of exchange rate pass-through into import prices. The results obtained suggest that exchange rate pass-through into import prices is about 50 per cent, that is, a 1 per cent depreciation of the rupee vis-a-vis its trading partners' currencies, results in import prices increasing by around 0.5 per cent, within a period of about 8 months. Second, prices along the pricing chain, namely, factor input prices (wages), trade (import and export) prices, wholesale producer prices and retail consumer prices, were examined to determine their response to a depreciation/appreciation of the rupee vis-a-vis its trading partners' currencies, taking a VAR approach. The results obtained for the structural VAR model suggest that consumer prices increase by around 0.3 per cent in response to a 1 per cent depreciation of the nomina effective exchange rate. The pass-through into wholesale producer prices was found to be much larger, with complete pass-through within a period of about 6 months. Factor input prices (worker compensation) were found to increase by around 0.5 per cent in response to an appreciation of the nominal effective exchange rate by 1 per cent. Import prices were found to respond by a relatively much larger magnitude than export prices, to a change in the exchange rate (import and export prices included in the model were the trade weighted indices), which implies that movements in the exchange rate has significant implications for the trade balance.

It was the intention of the researcher to ascertain by way of a Chow test, whether a change has occurred in the degree of exchange rate pass-through into import prices following the floating of the rupee in January 2001. However, given that the exchange rate impacts on import prices with a lag, the number of observations before January 2001 are not sufficient to do so. The main restriction was that the relevant data are not available. In particular, data on the nominal effective exchange rate, which has 1999 as its base year, are available only from 2000. One could perhaps extend backwards the relevant data series by using the appropriate statistical methods, in order to ascertain whether any significant changes have occurred in exchange rate pass-through in Sri Lanka. 


\section{References}

Appendix I

Adofson, Malin, 2001, "Monetary Policy with Incomplete Exchange Rate Pass-Through", Working Paper No.127, Sveriges Riksbank.

Campa, Jose Manuel and Goldberg, Linda S., 2002, "Exchange Rate Pass-Through into Import Prices: a Macro or Micro Phenomenon?”, Working Paper 8934, National Bureau of Economic Research.

De Fiore, Fiorella, 1998, “The Transmission of Monetary Policy in Israel”, IMF Working Paper 98/114.

Devereux, Michael B. and Yetman James, 2003, "Price-Setting and Exchange Rate Pass-Through: Theory and Evidence".

Faruqee, Hamid, 2004, "Exchange Rate Pass-Through in the Euro Area: The Role of Asymmetric Pricing Behaviour”, IMF Working Paper, 04/14.

Gagnon, Joseph E. and Ihrig, Jane, 2004, "Monetary Policy and Exchange Rate Pass-Through".

Kiptui, Moses; Ndolo, Daniel and Kaminchia, Sheila, 2005, "Exchange Rate Pass-Through: To What Extent do Exchange Rate Fluctuations affect Import Prices and Inflation in Kenya?", Working Paper No. 1, Central Bank of Kenya.

Mishkin, Frederic S., 1996, "The Channels of Monetary Transmission: Lessons for Monetary Policy", working paper 5464, National Bureau of Economic Research.

Taylor, John B., 2000, "Low Inflation, Pass-Through, and the Pricing Power of Firms", European Economic Review.

Walter Enders, 1995, “Applied Econometric Time Series".

Wijesinghe D. S.,1990, "Exchange rate changes and their impact on inflation", Central Bank of Sri Lanka, Staff Studies Volume 20. 
Results of the Tests for the Presence of a Unit Root -

Variables included in Model I

\section{Results of Unit Root Tests:}

\begin{tabular}{lccl}
\hline Variables (in logs) - & \multicolumn{2}{c}{ Included } & ADF Test $^{*}$ \\
\hline \multicolumn{1}{c}{ in Levels } & Constant & Trend & Statistic \\
\hline CCPI-Expenditure on Imports(Proxy for Import Prices) & Yes & Yes & $-2.5055^{1,2,3}$ \\
Foreign Prices (cost proxy) & Yes & Yes & $-2.3471^{1,2,3}$ \\
NEER (5-Currency Basket) & Yes & Yes & $-1.0755^{1,2,3}$ \\
Industrial Production Index(Proxy for GDP) & Yes & Yes & $1.5571^{1,2,3}$ \\
\hline
\end{tabular}

1/ I(1): Significant at $10 \%$ level

2/ I(1): Significant at $5 \%$ level

3/ I(1): Significant at $1 \%$ level

* Augmented Dickey-Fuller test

\section{Results of Unit Root Tests:}

\begin{tabular}{lcclll}
\hline First Difference of & \multicolumn{2}{c}{ Included } & ADF Test & KPSS Test $^{* *}$ \\
\hline Variables (in logs) & Constant & Trend & Statistic & \\
\hline CCPI-Expenditure on & Yes & Yes & $-8.24011,2,3$ & \\
Imports(Proxy for Import Prices) & & & & \\
Exporter Costs (cost proxy) & Yes & Yes & $-7.21131,2,3$ & \\
NEER (5-Currency Basket) & Yes & Yes & $-8.01291,2,3$ & \\
Industrial Production Index(Proxy & Yes & Yes & -2.91934 & $0.02781,2,3$ \\
for GDP) & & & & & \\
\hline
\end{tabular}

1/ I(0): Significant at $10 \%$ level

2/ I(0): Significant at $5 \%$ level.

$3 /$ I(0): Significant at $1 \%$ level.

$4 / \mathrm{l}(1)$

* Augmented Dickey-Fuller (ADF) test was carried out for all the variables.

** Kwiatkowski-Phillips-Schmidt-Shin (KPSS) test was carried out, when the differenced series was found to have a unit root, given the possibility of it being a near unit-root series.
Results of the Tests for the Presence of a Unit Root -

Variables included in Model II

\section{Results of Unit Root Tests:}

\begin{tabular}{|c|c|c|c|}
\hline Variables (in logs) - & & & ADF Test' \\
\hline in Levels & Constant & Trend & Statistic \\
\hline NEER (5-Currency Basket) & Yes & Yes & $-1.0755^{1,2,3}$ \\
\hline Real Wage Rate Indexa & Yes & Yes & $-3.9714^{3}$ \\
\hline $\begin{array}{l}\text { Import Prices (Trade weighted unit value } \\
\text { index for prices in USD terms) }\end{array}$ & Yes & Yes & $-2.1453^{1,2,3}$ \\
\hline $\begin{array}{l}\text { Export Prices (Trade weighted unit value } \\
\text { index for prices in USD terms) }\end{array}$ & Yes & Yes & $-4.1007^{4}$ \\
\hline $\begin{array}{l}\text { Intermediate Prices-WPI (proxy for whole- } \\
\text { sale producer prices) }\end{array}$ & Yes & Yes & $-5.4763^{4}$ \\
\hline $\mathrm{CCPI}$ & Yes & Yes & $-2.9954^{1,2,3}$ \\
\hline
\end{tabular}

a Real Wage Rate Index for Workers in the Wages Board Trades is the combined index for workers in Agriculture, Industry and Commerce, and Services.

I/ (1): Significant at $10 \%$ level

1(1): Significant at $5 \%$ leve

Augmented Dickey-Fuller test

Results of Unit Root Tests:

\begin{tabular}{lccl}
\hline First Difference of & \multicolumn{2}{c}{ Included } & \multicolumn{1}{l}{ ADF Test $^{*}$} \\
\hline Variables (in logs) & Constant & Trend & Statistic \\
\hline NEER (5-Currency Basket) & Yes & Yes & $-8.0129^{1,2,3}$ \\
$\begin{array}{l}\text { Real Wage Rate Indexa (proxy for factor } \\
\text { input prices) }\end{array}$ & Yes & Yes & $-6.9653^{1,2,3}$ \\
$\begin{array}{l}\text { Import Prices (Trade weighted unit value } \\
\text { index for prices in USD terms) }\end{array}$ & Yes & Yes & $-9.0589^{1,2,3}$ \\
$\begin{array}{l}\text { Export Prices (Trade weighted unit value } \\
\text { index for prices in USD terms) }\end{array}$ & Yes & Yes & $-9.4971^{1,2,3}$ \\
$\begin{array}{l}\text { Intermediate Prices - WPI (proxy for whole- } \\
\text { sale producer prices) }\end{array}$ & Yes & Yes & $-13.2803^{1,2,3}$ \\
CCPI & Yes & Yes & $-7.782^{1,2,3}$ \\
\hline
\end{tabular}

1/ I(0): Significant at $10 \%$ level

2/ I(0): Significant at $5 \%$ level

3/ I(0): Significant at $1 \%$ level

* Augmented Dickey-Fuller test 